\title{
Identification of new NBOH drugs in seized blotter papers: 25B-NBOH, 25C-NBOH, and 25E-NBOH
}

\author{
Yuri Machado ${ }^{1,2}$ - José Coelho Neto ${ }^{1,3} \cdot$ Rogério Araújo Lordeiro $^{1} \cdot$ Rosemeire Brondi Alves $^{2} \cdot$ Evandro Piccin $^{2}$
}

Received: 7 September 2019 / Accepted: 15 November 2019 / Published online: 2 December 2019

(c) The Author(s) 2019

\begin{abstract}
Purpose The recreational drug market remains dynamic. After the introduction of 25I-NBOH, an $N$-benzylphenethylamine and new psychoactive substance, as option for LSD and NBOMe drugs, new NBOH substances have been identified in recent years. Herein, we report our efforts for the identification and structural elucidation of three new NBOHs detected in seized blotter papers: 25B-NBOH, 25C-NBOH, and 25E-NBOH.

Methods Blotter papers seized between 2017 and 2018 by local police force in Brazil were submitted to extraction, purification, identification and characterization using attenuated total reflectance-Fourier transform infrared spectroscopy, gas chromatography—mass spectrometry, liquid chromatography—tandem mass spectrometry, and one- and two-dimensional nuclear magnetic resonance spectroscopy.

Results Three new NBOHs were characterized: 2-(((4-ethyl-2,5-dimethoxyphenethyl)amino)methyl)phenol (25E-NBOH, 2C-E-NBOH), 2-(((4-chloro-2,5-dimethoxyphenethyl)amino)methyl)phenol (25C-NBOH, 2C-C-NBOH), and 2-(((4-bromo2,5-dimethoxyphenethyl)amino)methyl)phenol (25B-NBOH, 2C-B-NBOH).

Conclusions To our knowledge, this is the first report for identification and detailed characterization of 25B-NBOH, 25C-NBOH, and 25E-NBOH in seized samples. NBOH substances are not under United Nations Conventions control. The identification of seized blotter papers between 2014 and beginning of 2019 showed that NBOH substances have become the main hallucinogenic drug in the region. These group are thermolabile under gas chromatographic conditions, demanding other analytical approaches of analysis to avoid misidentifications. Unfortunately, the knowledge about toxicology of NBOHs are limited.
\end{abstract}

Keywords $\mathrm{NBOH} \cdot 5-\mathrm{HT}_{2 \mathrm{~A}}$ receptor agonist $\cdot$ New psychoactive substances $\cdot$ Phenethylamines $\cdot$ Seized material $\cdot$ Chemical characterization

Yuri Machado

yurimachad@gmail.com

1 Seção Técnica de Física e Química Legal, Divisão de Laboratórios, Instituto de Criminalística da Polícia Civil de Minas Gerais, Avenida Augusto de Lima, 1833, Belo Horizonte, MG 30180-060, Brazil

2 Departamento de Química, Instituto de Ciências Exatas, Universidade Federal de Minas Gerais, Avenida Antônio Carlos, 6627, Belo Horizonte, MG CEP 31270-901, Brazil

3 Departamento de Física e Química, Instituto de Ciências Exatas e Informática, Pontifícia Universidade Católica de Minas Gerais, Avenida Dom José Gaspar, 500, Belo Horizonte, MG CEP 30535-901, Brazil

\section{Introduction}

New psychoactive substances (NPS) have become a global and continuously growing phenomenon over the last decade, posing a risk to public health while remaining a challenge to law enforcement agencies [1, 2]. From 2009 to 2017, over 800 NPS have been reported in 111 countries and territories, most of them being classified as phenethylamines, synthetic cathinones or synthetic cannabinoids [3].

Phenethylamines are agonists of the serotonin (5-HT, 5-hydroxytryptamine) receptors [4]. The $N$-benzyl substitution in phenethylamines (usually from the $2 \mathrm{C}$-X family, such as $2 \mathrm{C}-\mathrm{I}$ and $2 \mathrm{C}-\mathrm{B}$ ) improve the binding and functional activity in 5-HT receptors, with $\mathrm{N}$-(2-hydroxybenzyl) substituted substances usually presenting the highest affinities to the 5-HT $2 \mathrm{~A}$ receptor [4-6]. 
Since 2015, a new NPS group based on $N$-benzyl2,5-dimethoxyphenethylamines (Fig. 1), commonly described as NBOHs, emerged as recreational drugs. NBOHs, substances structurally closely related to NBOMes, are usually found on blotter papers and have become an option for LSD (lysergic acid diethylamide) users. Selfreported use of NBOHs has been reported in United States [7], Australia [8], and Germany [9]. These substances were already identified for street samples seized in Brazil [10], Finland, Germany, and Slovenia [11].

Like most NPS, knowledge about the toxicology of $\mathrm{NBOHs}$ is very limited or virtually nonexistent. According to information gathered from user forums (not to be considered as canon), the effects include tachycardia, and auditory and visual hallucinations $[12,13]$. While both NBOHs and NBOMes apparently taste bitter, thus providing a simple way for users to distinguish them from LSD [14], NBOHs are reported to induce weaker effects and to last less than NBOMes, being unaccompanied with "body load", an unpleasant physical sensation reported by drug users [14].

Together with usual difficulties associated with the identification of NPS (unknown substance, never before reported, not present in reference spectral libraries, no certified standards available, etc), detection of NBOHs present yet another important trait: thermal degradation under standard gas chromatography, which seriously increases the risk of misidentification $[15,16]$ and demands the development of other detection methods [17-21].

Herein, we report our efforts for the identification and structural elucidation of three new NBOHs detected in seized samples submitted to our forensic laboratory: 25B-NBOH, 25C-NBOH and 25E-NBOH.

\section{Materials and methods}

\section{Chemicals and reagents}

Acetone, chloroform, diethyl ether, methanol, sodium hydroxide, and hydrochloric acid were purchased from Synth (Diadema, SP, Brazil); methanol LC grade from Merck (Darmstadt, Germany); ammonium formate and methanol- $d_{4}$ with $99.8 \%$ isotopic purity, containing $0.03 \%$ $(\mathrm{v} / \mathrm{v})$ tetramethylsilane (TMS), from Sigma-Aldrich (St. Louis, MO, USA); the ultrapure water from Milipore Direct Q3 (Billerica, MA, USA); silica gel 60 (70-230 mesh) from Merck.

\section{Samples and extraction}

Blotter papers suspected to contain illicit substances were seized between 2017 and 2018 by police forces from Minas Gerais. These blotters usually represented a colorful side<smiles>[R]c1cc(OC)c(CCN)cc1OC</smiles><smiles>COc1cc(CCNCc2ccccc2OC)c(OC)cc1P</smiles><smiles>[R]c1cc(OC)c(CCNCc2ccccc2O)cc1OC</smiles>

$\mathrm{R}=$ Alkyl, halogen or hydrogen<smiles>COc1cc(CCN)c(OC)cc1I</smiles><smiles>COc1cc(CCN)c(OC)cc1Br</smiles><smiles>COc1cc(CCN)c(OC)cc1Cl</smiles><smiles>COc1cc(CCNCc2ccccc2OC)c(OC)cc1I</smiles><smiles>COc1cc(CCNCc2ccccc2OC)c(OC)cc1Br</smiles><smiles>COc1cc(CCNCc2ccccc2OC)c(OC)cc1Cl</smiles><smiles>COc1cc(CCNCc2ccccc2O)c(OC)cc1I</smiles>

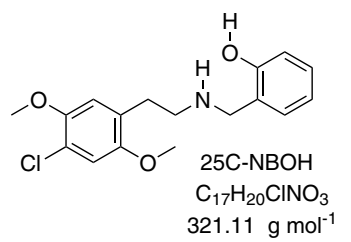
$365.06 \mathrm{~g} \mathrm{~mol}^{-1}$ $321.11 \mathrm{~g} \mathrm{~mol}^{-1}$

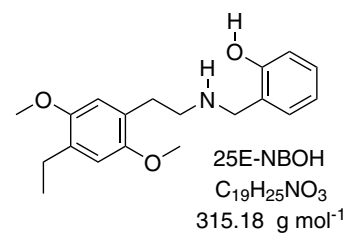

Fig. 1 Structures of $N$-benzylphenethylamines: 2Cs, 2C-I, 2C-B, and 2C-C; NBOMes 25I-NBOMe, 25B-NBOMe, and 25C-NBOMe; NBOHs 25I-NBOH, 25B-NBOH, 25C-NBOH, 25H-NBOH, and 25E-NBOH 
including drawings of cartoon and game characters, scientists, deities, etc. and a white side (Fig. 2). The samples were grouped according to previous routine analysis, such as gas chromatography-mass spectrometry (GC-MS) and liquid chromatography-tandem mass spectrometry (LC-MS/MS), as follows: one hundred blotter papers for samples named as $\mathbf{0 1}$ and $\mathbf{0 2}$, and twenty-five blotter papers for sample named as $\mathbf{0 3}$.

Each sample group $(\mathbf{0 1}, \mathbf{0 2}$, and $\mathbf{0 3})$ was submitted to three successive extractions: $30 \mathrm{~mL}$ of chloroform $(2 \times)$ and $30 \mathrm{~mL}$ of methanol in beakers by $20 \mathrm{~min}$ in magnetic stirrer. After mixing the $90 \mathrm{~mL}$ of solvent extracted, $1 \mathrm{~mL}$ of $\mathrm{NaOH}$ solution $(1 \%, w / v)$ was added. Each solution was evaporated to dryness getting a solid reddish residue. Each residue was submitted to column chromatography using silica gel as stationary phase. The elution was performed with chloroform, acetone, and methanol, in increasing polarity order, providing the corresponding fractions. The acetone fraction was evaporated to dryness and $20 \mathrm{~mL}$ of saturated solution of hydrochloric acid in diethyl ether was added to the residue, providing, after new evaporation to dryness, a beige solid labeled as compound $\mathbf{0 1}(15.1 \mathrm{mg})$, compound $\mathbf{0 2}(13.3 \mathrm{mg})$, and compound $\mathbf{0 3}(4.5 \mathrm{mg})$.

\section{Instrumentation}

\section{Attenuated total reflectance Fourier transform infrared spectroscopy analysis}

Attenuated total reflectance Fourier transform infrared spectroscopy (ATR-FTIR) analyses were performed directly from the solids, except for compound $\mathbf{0 3}$ due to the small amount available. They were obtained using a NicoletTM iZ10 spectrometer equipped with EverGlo infrared (IR) source, DLaTGS room temperature IR detector under $\mathrm{N}_{2}$ purge and single-bounce Smart Orbit ${ }^{\mathrm{TM}}$ accessory module with diamond ATR crystal (Thermo Fischer Scientific, Madison, WI, USA). Each spectrum was averaged over 16 scans, taken at $4 \mathrm{~cm}^{-1}$ resolution, with maximum detector window aperture and minimum interferometer mirror speed, in the range of $400-4000 \mathrm{~cm}^{-1}$.

\section{Gas chromatography-mass spectrometry analysis}

Samples were prepared by transferring $1 \mathrm{mg}$ of solid to a microcentrifuge tube and adding $1 \mathrm{~mL}$ of $\mathrm{LC}$ grade methanol. Each solution was transferred to a vial for analysis. Analysis were performed on an Agilent GC 7890A (Agilent Technologies, Santa Clara, CA, USA) coupled with an Agilent XL MSD 5975C quadrupole mass spectrometer. The chromatographic separation was performed with a 433 HP-1MS capillary column $(30 \mathrm{~m} \times 0.25 \mathrm{~mm}$, i.d., film thickness $0.25 \mu \mathrm{m}$; Agilent Technologies). A volume of $1 \mu \mathrm{L}$ of the sample solution was injected with a split ratio of 20:1. Helium was used as carrier gas with a constant flow of $1.0 \mathrm{~mL} \mathrm{~min}^{-1}$. The temperature of injector and the GC-MS interface was set at 280 and $300^{\circ} \mathrm{C}$, respectively. The oven temperature was initially maintained at $150^{\circ} \mathrm{C}$ for $1.5 \mathrm{~min}$; increased to $250^{\circ} \mathrm{C}$ at $30^{\circ} \mathrm{C} \mathrm{min}^{-1}$ and maintained for $1 \mathrm{~min}$; increased to $300^{\circ} \mathrm{C}$ at $50^{\circ} \mathrm{C} \mathrm{min}^{-1}$ and maintained for $3 \mathrm{~min}$ (total run time: $11.8 \mathrm{~min}$ ). The solvent delay was set to $1.5 \mathrm{~min}$. The mass scan range was set to $\mathrm{m} / \mathrm{z}$ 35-550.
Fig. 2 Appearances of blotter papers containing illicit substances

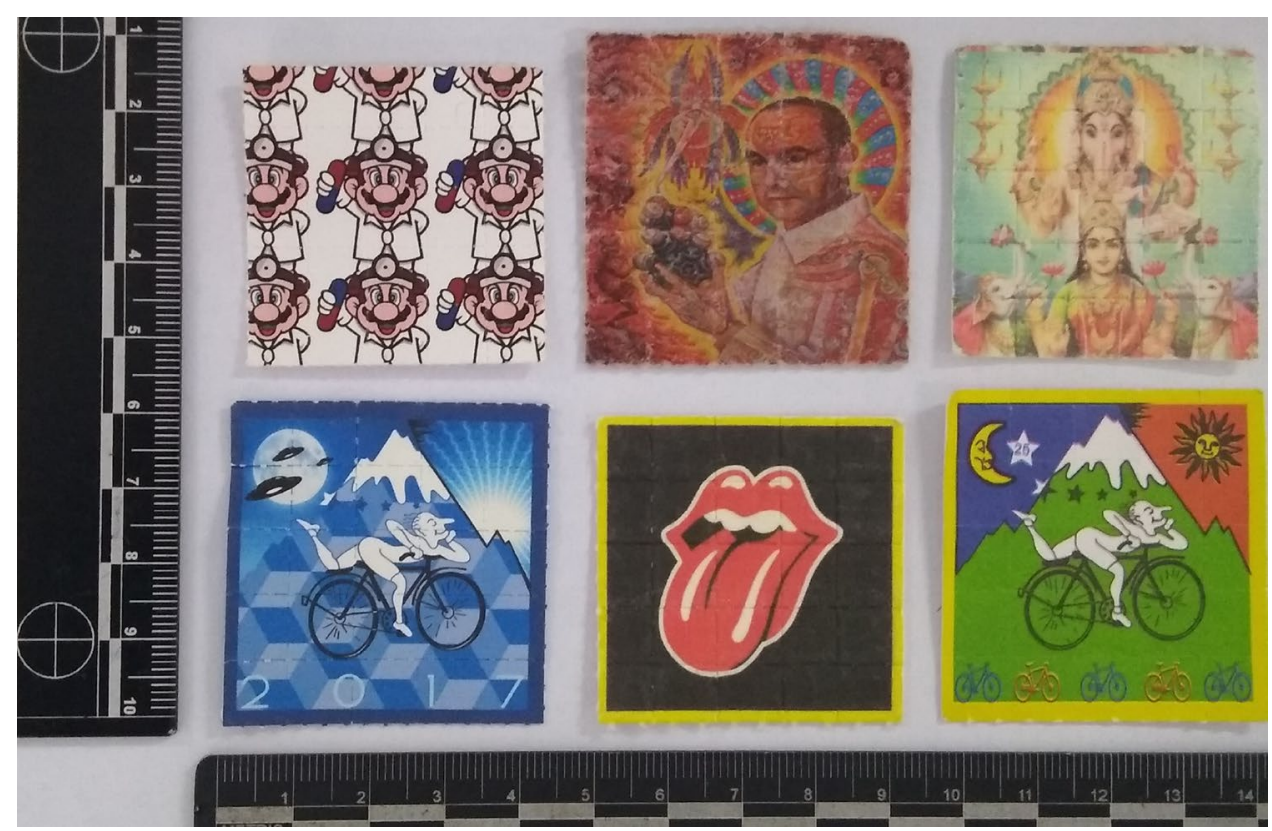




\section{Liquid chromatography coupled to tandem mass spectrometry analysis}

LC-MS/MS analyses were performed on a Prominence UFLC system (Shimadzu Corporation, Kyoto, Japan) coupled with a Shimadzu LCMS 8030 triple quadrupole mass spectrometer with electrospray ionization source (ESI) set in the positive ionization mode. LabSolutions ${ }^{\mathrm{TM}}$ (Shimadzu Corporation) was used for data acquisition and processing.

Direct flow injections were performed with a total flow rate of $0.4 \mathrm{~mL} \mathrm{~min}{ }^{-1}$. The mobile phase consisted of $50 \%$ of ultra-pure water (A) and $50 \%$ of acetonitrile (B), both containing ammonium formate $(0.024 \%, \mathrm{w} / \mathrm{v})$. The injection volume was $1 \mu \mathrm{L}$ and the total run time was $1 \mathrm{~min}$.

The MS conditions were as follows: desolvation line temperature, $250^{\circ} \mathrm{C}$; heat block temperature, $400^{\circ} \mathrm{C}$; nebulizing gas flow, $3 \mathrm{~L} \mathrm{~min}^{-1}$; drying gas flow, $15 \mathrm{~L} \mathrm{~min}^{-1}$; collisioninduced dissociation (CID) gas pressure, $230 \mathrm{kPa}$; dwell time, $100 \mathrm{~ms}$; and interface voltage, $4.5 \mathrm{kV}$. A Q3 full scan were set from $\mathrm{m} / \mathrm{z} 110$ to 500 to seek out the protonated molecule $\left([\mathrm{M}+\mathrm{H}]^{+}\right)$, and product ion scan (PIS) were performed with collision energies of $-10,-20,-30$, and $-40 \mathrm{eV}$ for the purpose of analyzing the fragmentation pattern.

\section{Nuclear magnetic ressonance spectroscopy analysis}

The nuclear magnetic resonance (NMR) experiment was conducted using $12 \mathrm{mg}$ of compound $\mathbf{0 1}, 12 \mathrm{mg}$ of compound $\mathbf{0 2}$ and $3.5 \mathrm{mg}$ of compound $\mathbf{0 3}$. Each solid was dissolved in $0.6 \mathrm{~mL}$ methanol- $d_{4}$ with tetramethylsilane (TMS) as internal standard. ${ }^{1} \mathrm{H},{ }^{13} \mathrm{C}$, DEPT 135 (Distortionless Enhancement by Polarization Transfer), HSQC (Heteronuclear Single Quantum Coherence) and HMBC (Heteronuclear Multiple-Bond Correlation) experiments were recorded using a Bruker Avance DRX $600 \mathrm{MHz}$ spectrometer (Bruker, Ettlingen, Germany). Acquisition was conducted by TopSpin software 4.0.6 version (Bruker) and processing was conduct by MestReNova 12.0 (MestreLab Research, Santiago de Compostela, Spain).

\section{Results}

\section{ATR-FTIR analysis}

ATR-FTIR spectra of compounds $\mathbf{0 1}$ and $\mathbf{0 2}$ indicated the presence of small impurities that were not eliminated during the purification processes. The single infrared spectral profile analysis using available forensic libraries (SWGDRUG and Europe Response infrared library) indicated presence of signals matching with $\mathrm{NBOH}$ drugs [22, 23]. Interpretation of the ATR-FTIR spectra indicated the same findings from our previous work [15]: the higher degree of similarity with 25R-NBOMe when compared with 2C-R and a systematic decrease of the spectral band centered around $1250 \mathrm{~cm}^{-1}$, characteristic of asymmetric $\mathrm{C}-\mathrm{O}-\mathrm{C}$ vibrations of $\mathrm{NBOMe}$ compounds, indicating the substitution of $\mathrm{OCH}_{3}$ by $\mathrm{OH}$ (Fig. 3).

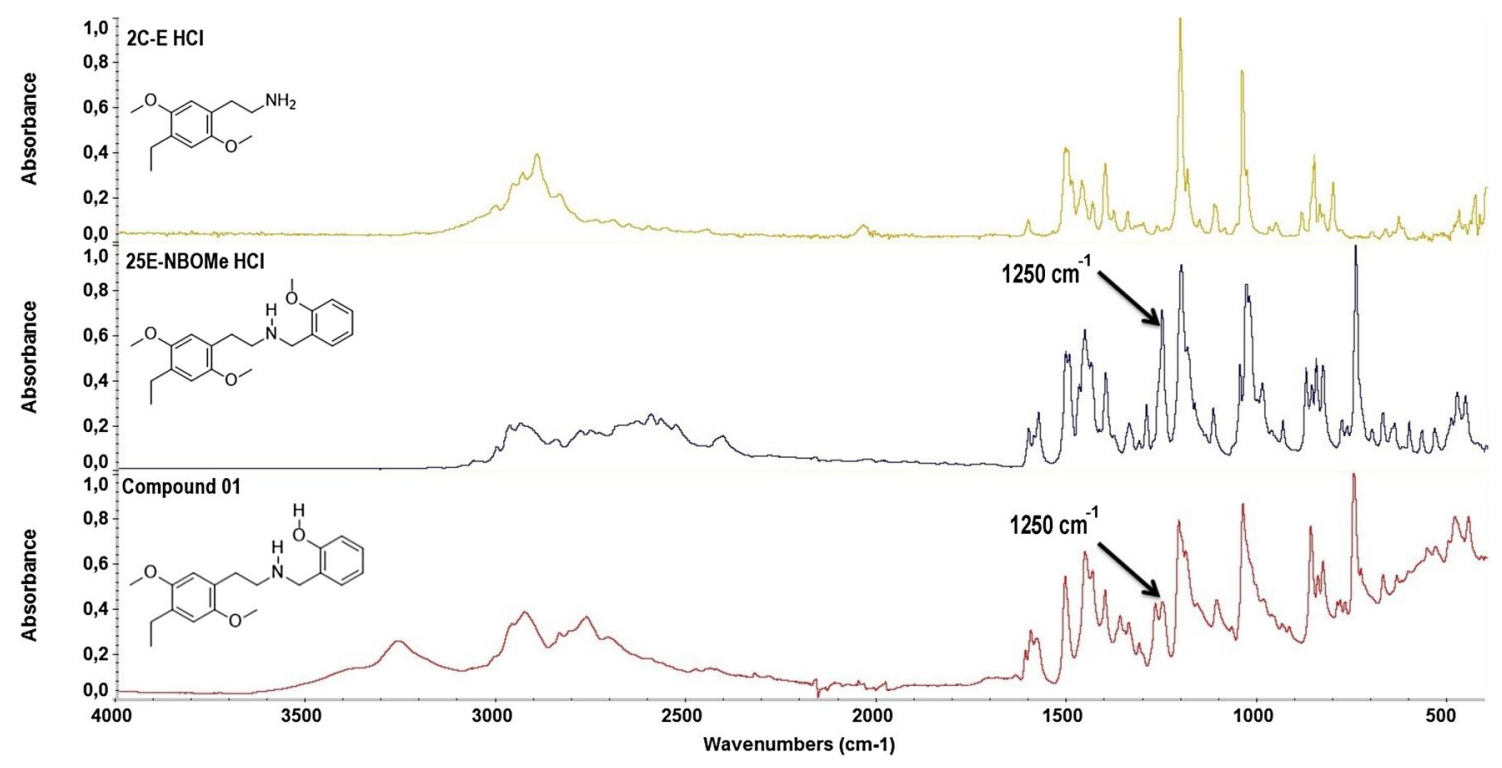

Fig. 3 Comparison of infrared (IR) spectrograms for 2C-E (from SWGDRUG IR library), 25E-NBOMe (from SWGDRUG IR Library version 2.0), and compound $\mathbf{0 1}$, identified as $25 \mathrm{E}-\mathrm{NBOH}$. The arrows show the decrease of spectral band indicating the substitution of $\mathrm{OCH}_{3}$ by $\mathrm{OH}$ in the $25 \mathrm{E}-\mathrm{NBOH}$ 
Fig. 4 Total ion chromatograms by gas chromatography-mass spectrometry (GC-MS) for samples 01 (25E-NBOH), $\mathbf{0 2}(25 \mathrm{C}-\mathrm{NBOH})$ and $\mathbf{0 3}$ (25B-NBOH), and respective mass spectra of the main peaks
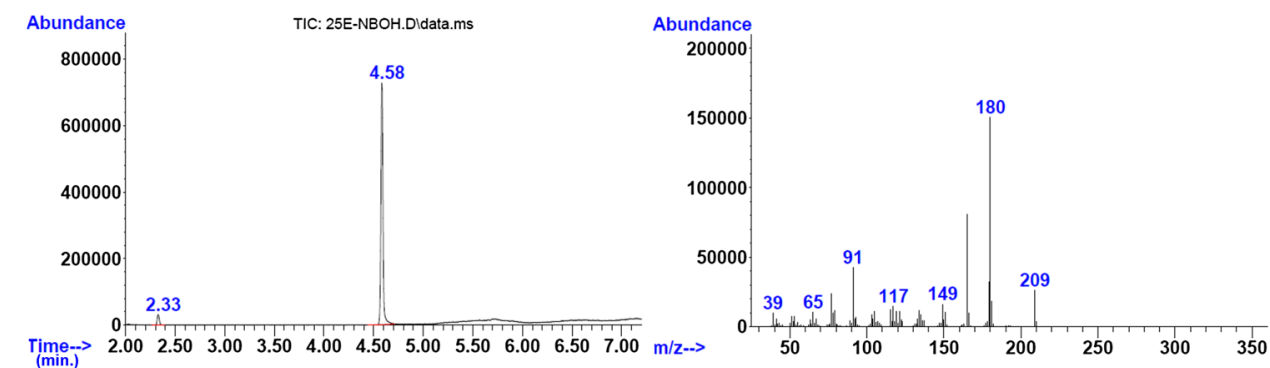

Abundance

TIC: 25C-NBOH.DIdata.ms

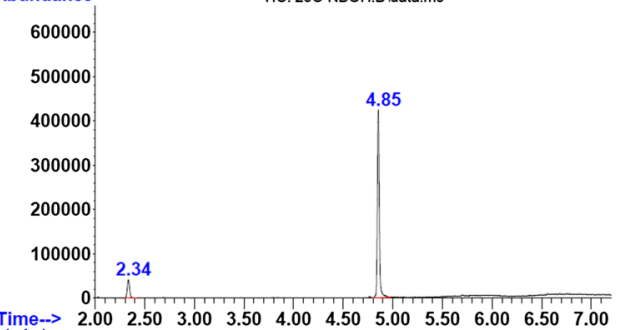

Abundance

100000

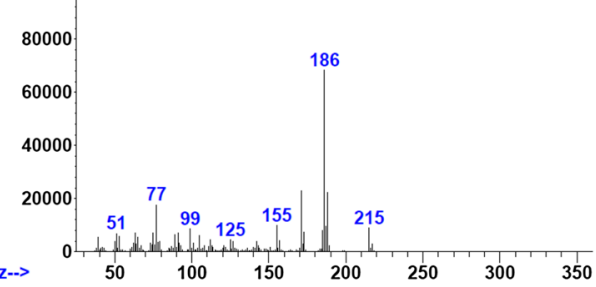

(min.)

Abundance

TIC: 25B-NBOH.DIdata.ms

5.15
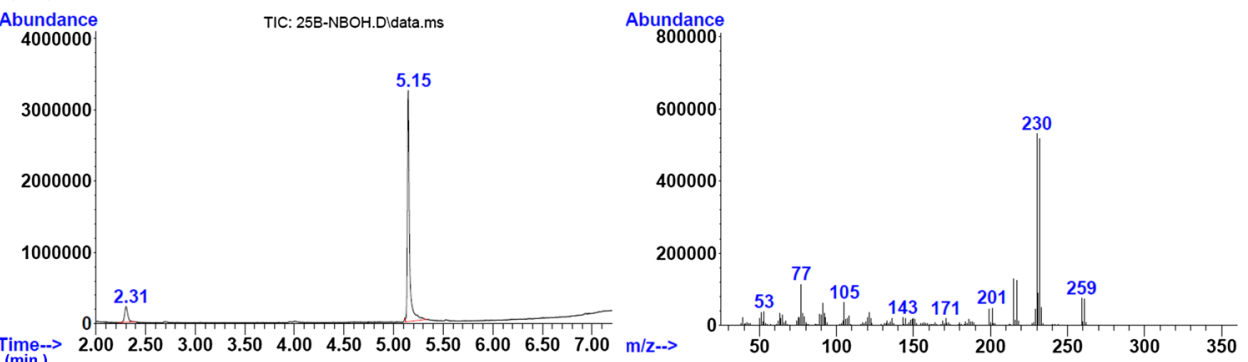

Table 1 Gas chromatographymass spectrometry ion data for analyzed samples

\begin{tabular}{llllll}
\hline Formula & Proposed ion & \multicolumn{1}{l}{ Ion $(m / z)$} & & \\
\cline { 3 - 6 } & & $-\mathrm{R}$ & & & \\
\cline { 3 - 5 } & & $-\mathrm{CH}_{2} \mathrm{CH}_{3}$ & $-\mathrm{Cl}$ & $-\mathrm{Br}$ & $-\mathrm{I}$ \\
& & $(25 \mathrm{E}-\mathrm{NBOH})$ & $(25 \mathrm{C}-\mathrm{NBOH})$ & $(25 \mathrm{~B}-\mathrm{NBOH})$ & $(25 \mathrm{I}-\mathrm{NBOH})$ \\
\hline $\mathrm{C}_{10} \mathrm{H}_{14} \mathrm{NO}_{2} \mathrm{R}^{+.}$ & $180+\mathrm{R}$ & 209 & 215 & 259 & 307 \\
$\mathrm{C}_{9} \mathrm{H}_{11} \mathrm{O}_{2} \mathrm{R}^{+}$ & $151+\mathrm{R}$ & 180 & 186 & 230 & 278 \\
$\mathrm{C}_{8} \mathrm{H}_{8} \mathrm{O}_{2} \mathrm{R}^{+}$ & $136+\mathrm{R}$ & 165 & 171 & 215 & 263 \\
$\mathrm{C}_{8} \mathrm{H}_{8} \mathrm{OR}^{+}$ & $120+\mathrm{R}$ & 149 & 155 & 199 & 247 \\
\hline
\end{tabular}

Also see Fig. 6

\section{GC-MS analysis}

The GC-MS analysis of compounds $\mathbf{0 1}, \mathbf{0 2}$ and $\mathbf{0 3}$ (Fig. 4) indicated the presence of, respectively, 2C-E (RT: retention time $=4.58 \mathrm{~min}), 2 \mathrm{C}-\mathrm{C}(\mathrm{RT}=4.85 \mathrm{~min})$ and $2 \mathrm{C}-\mathrm{B}(\mathrm{RT}=$ $5.15 \mathrm{~min}$ ) as most intense peaks according to mass spectra library available (Table 1). The mass spectra for the secondary peaks $(\mathrm{RTs}=2.33,2.34$, and $2.31 \mathrm{~min}$, respectively; Fig. 5) were all similar but they had no reasonable match on MS libraries currently. These results have already been predicted for other $\mathrm{NBOHs}$ corroborating the finding that this group of substances are thermolabile under the GC temperature conditions [16]. Considering the results of mass spectrum libraries and the presence of secondary peaks, there was an indication that substances $\mathbf{0 1}, \mathbf{0 2}$ and $\mathbf{0 3}$ were 25E-NBOH, 25C-NBOH, and 25B-NBOH, respectively. The thermal fragmentation reactions and proposed mass fragmentation pathways for these substances are presented in Fig. 6 according to the previous works [16, 24].

\section{LC-MS/MS analysis}

The positive full scan and PIS mass spectra of compounds $\mathbf{0 1}, \mathbf{0 2}$, and $\mathbf{0 3}$ are presented in Fig. 7. For compound 02, the relative intensity of the ion at $\mathrm{m} / \mathrm{z} 322$ was 3:1 of signal at $\mathrm{m} / \mathrm{z} 324$. For compound $\mathbf{0 3}$, the relative intensity of the ion 


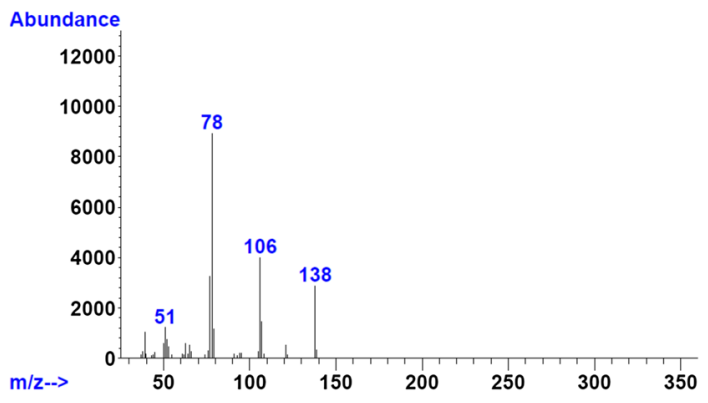

Fig. 5 GC-MS spectra of secondary peaks

at $m / z 368$ was $1: 1$ of signal at $m / z 370$. These isotopologue patterns indicate the presence of chlorine and bromine atoms in chemical structures of $\mathbf{0 2}$ and $\mathbf{0 3}$, respectively. The precursor ion and product ions of the analyzed substances (Fig. 8) are compatible with mass fragmentation pathway proposed in the previous works $[15,25]$ and can be summarized as shown in Table 2.

Fig. 6 Thermal fragmentation reaction produced by GC-MS, and proposed mass fragmentation pathways for 25R-NBOH/2C-R<smiles>[R]c1cc(OC)c(CCNCc2ccccc2O)cc1OC</smiles>

\section{NMR analysis}

NMR spectroscopic results of $\mathbf{0 1 ,} \mathbf{0 2}$, and $\mathbf{0 3}$ are presented in Tables 3, 4, and 5, respectively. Minor impurities were detected in the three spectra without prejudice to the data interpretation. All experiments $\left({ }^{1} \mathrm{H},{ }^{13} \mathrm{C}\right.$, DEPT 135 , HSQC and $\mathrm{HMBC}$ ) were used for characterizing $\mathbf{0 1}$ and $\mathbf{0 2}$. However, due to the limited amount of $\mathbf{0 3},{ }^{13} \mathrm{C}$ signals were assigned only by HSQC and HMBC experiments.

It was observed thirteen types of $\mathrm{H}$-signal (two of these signals were overlapped) and nineteen types of C-signal for compound $\mathbf{0 1}$; eleven types of $\mathrm{H}$-signal and seventeen types of C-signal for compound $\mathbf{0 2}$ and $\mathbf{0 3}$. In general, these signals, supported by HSQC and HMBC experiments, were attributed to one 1,2,4,5-tetra-substituted aromatic ring containing two methoxy, one ethylmethylamine group and an ethyl (01), chlorine (02) or bromine group (03). It was observed that the amine group was attached to one (2-hydroxyphenyl)methyl group. Based on structural elucidation using NMR, compound $\mathbf{0 1}$ was

GC thermal degradation
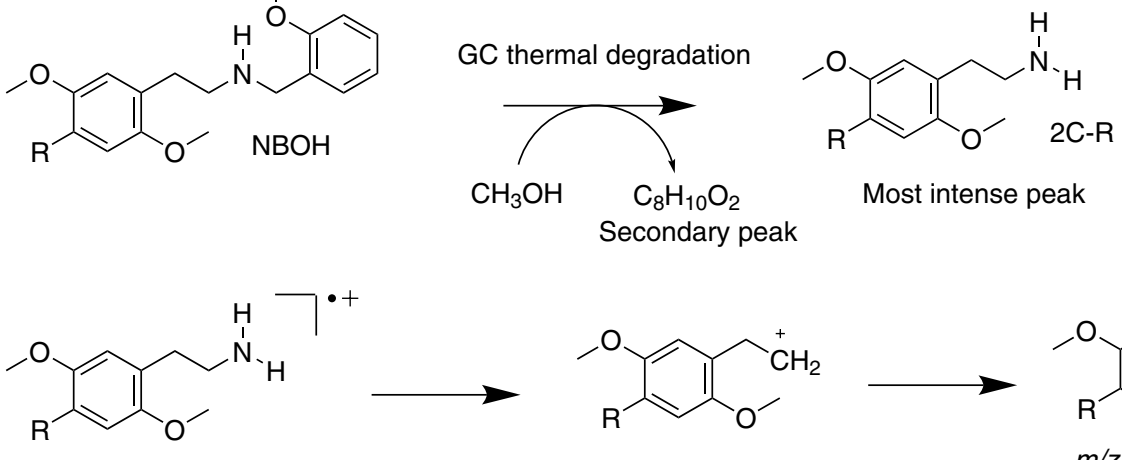
$m / z 180+R$<smiles>[R]c1cc(OC)c(C[CH2+])cc1OC</smiles><smiles>[R]C1=CC(OC)=[C+]C=C1OC</smiles><smiles>[R]c1cc([OH+]C)c(C)cc1OC</smiles>

$m / z 151+\mathrm{R}$<smiles>[R]c1ccc(I)cc1OC</smiles>

$m / z 120+R$ 


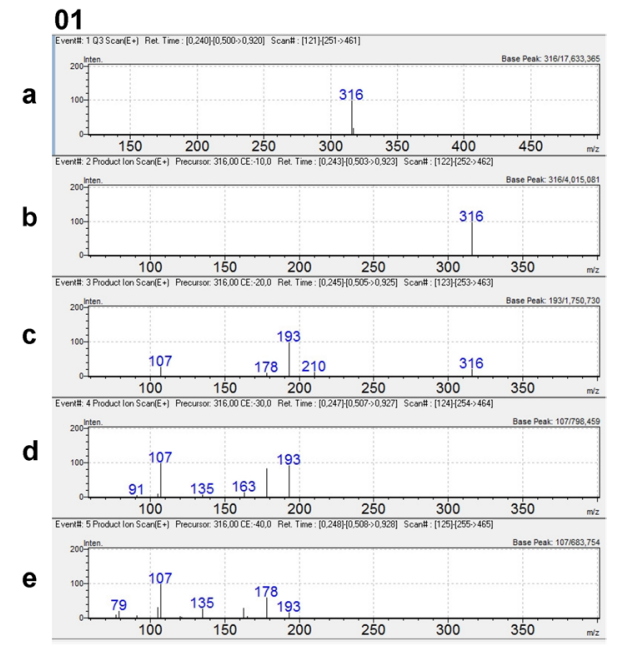

02

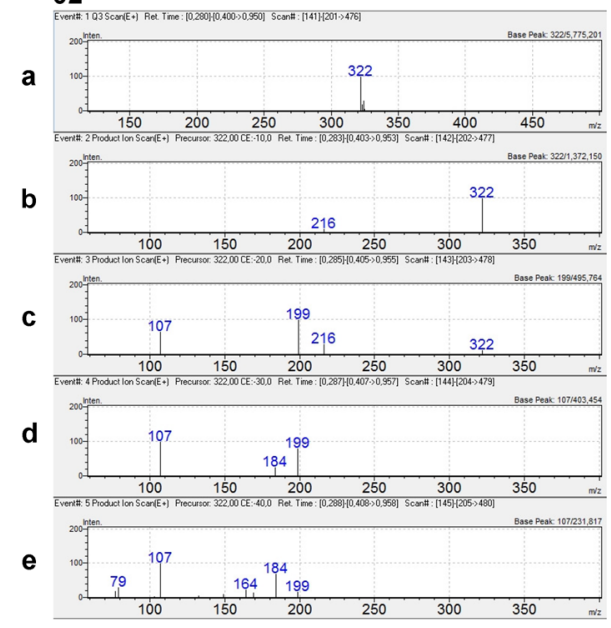

$$
03
$$

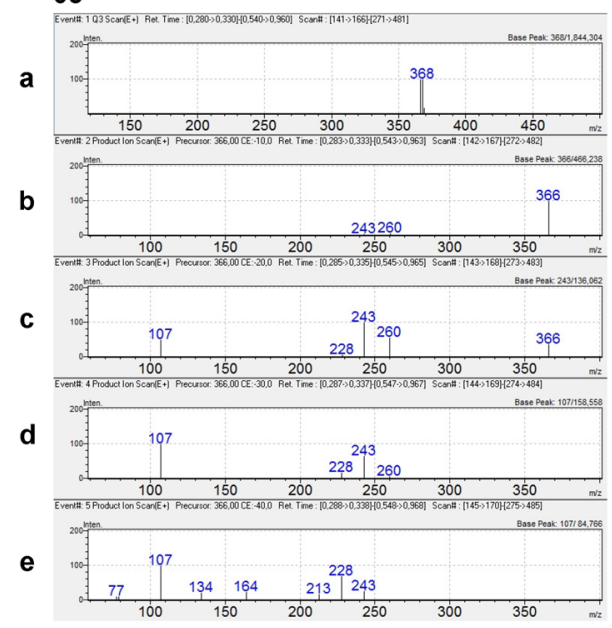

Fig. 7 Full scan mass spectra (a) and product ion spectra of 01 (25I-NBOH), $\mathbf{0 2}(25 \mathrm{C}-\mathrm{NBOH})$, and $\mathbf{0 3}(25 \mathrm{~B}-\mathrm{NBOH})$ at different collision energies of 10 (b), 20 (c), 30 (d), and $40 \mathrm{eV}$ (e) recorded by liquid chromatography-tandem mass spectrometry (LC-MS/MS) identified as 2-(((4-ethyl-2,5-dimethoxyphenethyl)amino) methyl)phenol (25E-NBOH, 2C-E-NBOH), compound 02 as 2-(((4-chloro-2,5-dimethoxyphenethyl)amino)methyl) phenol (25C-NBOH, 2C-C-NBOH), and compound $\mathbf{0 3}$ as 2-(((4-bromo-2,5-dimethoxyphenethyl)amino)methyl) phenol (25B-NBOH, 2C-B-NBOH). These data were in agreement with those observed by ATR-FTIR, GC-MS and LC-MS/MS.

\section{NBOH outlook}

The number of identifications of $N$-benzylphenethylamines (NBOMes and NBOHs) and LSD by our laboratory in seized samples between 2014 and the first semester of 2019 is shown in Fig. 9a, updating our previous work [10]. NBOMes dominated the blotter paper drug market up to the beginning of 2016. Starting at this point, NBOH identification has increased, overcoming NBOMes at the second semester of 2016. In contrast, the number of NBOMes identifications has decreased and are, nowadays, less significant than LSD (305 identifications of NBOHs, 86 of LSD and 20 of NBOMes, between July 2018 and June 2019).

From 2015 to 2017 , the only NBOH detected was 25I-NBOH. The other NBOHs (Fig. 9b) started appearing in the last two years, with 25B-NBOH first identified in 2017, and $25 \mathrm{C}-\mathrm{NBOH}$ and $25 \mathrm{E}-\mathrm{NBOH}$ in 2018 , totalizing 376 NBOHs identifications in blotter paper (Jan 2017 to Jun 2019). Although 25H-NBOH has been also identified in 2017, it was considered primarily as a minor component, always associated with other major component NBOHs, and was not included in the number of identifications considered until January 2018.

\section{Discussion}

To our knowledge, the present study is the first academical work to identify and to characterize $25 \mathrm{~B}-\mathrm{NBOH}$, 25C-NBOH, and 25E-NBOH in authentic street seized samples. With the addition of 25I-NBOH, the first substance of these group reported, NBOHs has become a consolidated option in the recreational drug market. Regarding the legal aspect, none of NBOH substances are controlled by any United Nations Conventions. Due to the efforts of local forensic laboratories, some $\mathrm{NBOH}$ are scheduled in Brazil as prohibited substances: 25I-NBOH (October 2016), 25B-NBOH, 25C-NBOH, 25E-NBOH and $25 \mathrm{H}-\mathrm{NBOH}$ (December 2018) [26]. Scheduling of the $N$-benzylphenethylamines seems to have impact in local drug market, namely decreasing the availability of scheduled drugs. The dynamics 
Fig. 8 Proposed mass fragmentation pathways for 25R-NBOH produced by LC-MS/MS
Table 2 Precursor and product ion data by liquid chromatography-tandem mass spectrometry for analyzed samples
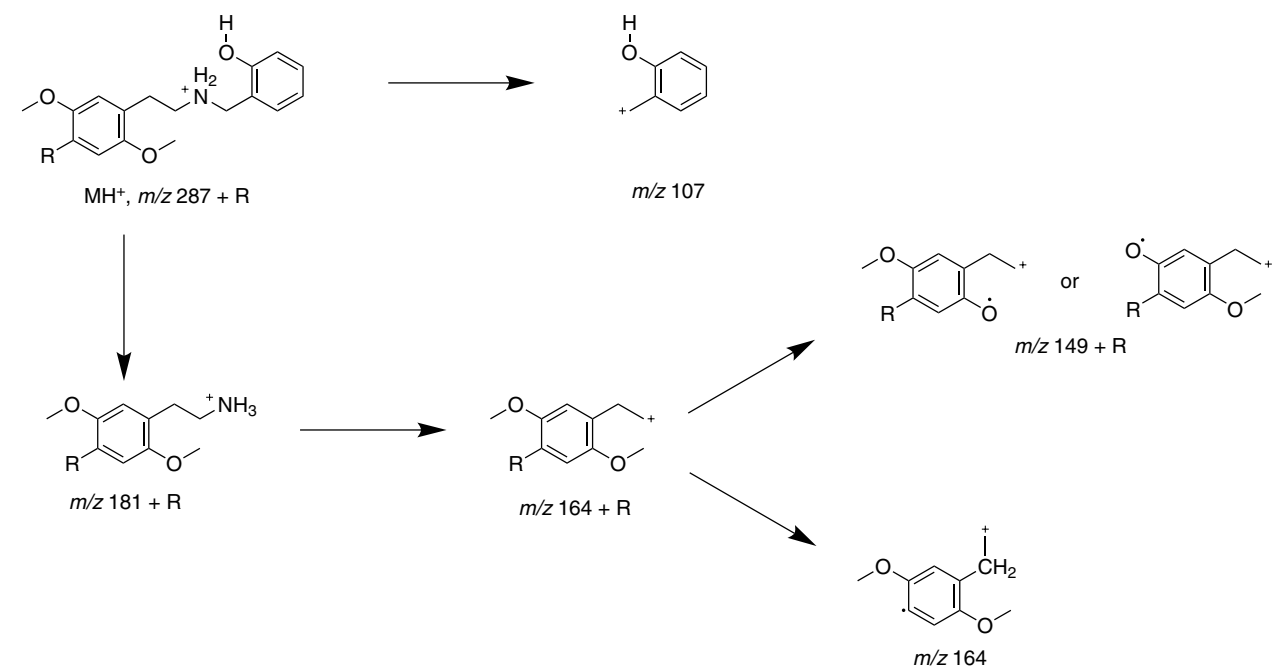

\begin{tabular}{llllll}
\hline Formula & Proposed ion & \multicolumn{2}{l}{ Ion $(m / z)$} & & \\
\cline { 3 - 6 } & & $-\mathrm{R}$ & & & \\
\cline { 3 - 6 } & & $-\mathrm{CH}_{2} \mathrm{CH}_{3}$ & $-\mathrm{Cl}$ & $-\mathrm{Br}$ & $-\mathrm{I}$ \\
& & $(25 \mathrm{E}-\mathrm{NBOH})$ & $(25 \mathrm{C}-\mathrm{NBOH})$ & $(25 \mathrm{~B}-\mathrm{NBOH})$ & $(25 \mathrm{I}-\mathrm{NBOH})$ \\
\hline $\mathrm{C}_{17} \mathrm{H}_{21} \mathrm{NO}_{3} \mathrm{R}^{+}$ & $287+\mathrm{R}$ & 316 & 322 & 368 & 414 \\
$\mathrm{C}_{10} \mathrm{H}_{15} \mathrm{NO}_{2} \mathrm{R}^{+}$ & $181+\mathrm{R}$ & 210 & 216 & 260 & 308 \\
$\mathrm{C}_{10} \mathrm{H}_{12} \mathrm{O}_{2} \mathrm{R}^{+}$ & $164+\mathrm{R}$ & 193 & 199 & 243 & 291 \\
$\mathrm{C}_{9} \mathrm{H}_{9} \mathrm{O}_{2} \mathrm{R}^{+}$ & $149+\mathrm{R}$ & 178 & 184 & 228 & 276 \\
$\mathrm{C}_{10} \mathrm{H}_{12} \mathrm{O}_{2}^{+.}$ & 164 & 164 & 164 & 164 & 164 \\
$\mathrm{C}_{7} \mathrm{H}_{7} \mathrm{O}^{+}$ & 107 & 107 & 107 & 107 & 107 \\
\hline
\end{tabular}

Also see Fig. 8 of such process, specially its rate, however, is not clearly enough; while an $\mathrm{NBOH}$ was first identified in a seized sample about 1.5 years after the ban of the corresponding NBOMe, newer NBOHs emerged only seven months after the ban of 25I-NBOH. Although these numbers help us to illustrate the dynamics of the drug market, they should not be considered accurately because they are significantly influenced by the agility of police investigation, seizures of drug materials and the ability of forensic laboratories to establish the identity of new substances.
The knowledge about pharmacology and toxicology of these NBOHs, as well others NPS, are limited. 25I-NBOH showed a higher selectivity for the $5-\mathrm{HT}_{2 \mathrm{~A}}$ receptor when compared to $5-\mathrm{HT}_{2 \mathrm{C}}$ (449.8-fold higher) followed by 25C-NBOH (43.7-fold higher), 25E-NBOH (31.0-fold higher), and 25B-NBOH (8.7-fold higher) [5]. Many studies on toxicokinetics and toxicodynamics of $\mathrm{NBOHs}$ remain to be explored. 
Table $3{ }^{1} \mathrm{H}$ and ${ }^{13} \mathrm{C}$ nuclear magnetic resonance (NMR) spectral data for compound $\mathbf{0 1}(25 \mathrm{E}-\mathrm{NBOH})$ obtained at $600 \mathrm{MHz}\left(\mathrm{methanol}-d_{4}\right)$<smiles>CCc1cc(OC)c(CCNCc2ccccc2O)cc1OC</smiles>

\begin{tabular}{|c|c|c|c|c|c|}
\hline \multirow[t]{2}{*}{ Position } & \multirow[t]{2}{*}{${ }^{1} \mathrm{H}[\delta(\mathrm{ppm}), \mathrm{M}, J(\mathrm{~Hz})$, Integral $]$} & \multirow[t]{2}{*}{${ }^{13} \mathrm{C}[\delta(\mathrm{ppm})]$} & \multirow[t]{2}{*}{ DEPT 135} & \multicolumn{2}{|l|}{ HMBC } \\
\hline & & & & ${ }^{2} J$ & ${ }^{3} J$ \\
\hline 1 & - & 122.0 & $\mathrm{C}$ & - & - \\
\hline 2 & - & 151.3 & $\mathrm{C}$ & - & - \\
\hline 3 & $6.79, \mathrm{~s}, 1 \mathrm{H}$ & 112.1 & $\mathrm{CH}$ & - & $\mathrm{C} 1, \mathrm{C} 12$ \\
\hline 4 & - & 132.6 & $\mathrm{C}$ & - & - \\
\hline 5 & - & 151.4 & $\mathrm{C}$ & - & - \\
\hline 6 & $6.78, \mathrm{~s}, 1 \mathrm{H}$ & 113.1 & $\mathrm{CH}$ & - & $\mathrm{C} 4, \mathrm{C} 7$ \\
\hline 7 & $2.99, \mathrm{t}, J=7.5,2 \mathrm{H}$ & 27.0 & $\mathrm{CH}_{2}$ & $\mathrm{C} 1, \mathrm{C} 8$ & $\mathrm{C} 2, \mathrm{C} 6$ \\
\hline 8 & $3.21, \mathrm{t}, J=7.5,2 \mathrm{H}$ & 47.0 & $\mathrm{CH}_{2}$ & $\mathrm{C} 7$ & $\mathrm{C} 1, \mathrm{C} 9$ \\
\hline 9 & $4.21, \mathrm{~s}, 2 \mathrm{H}$ & 46.9 & $\mathrm{CH}_{2}$ & $\mathrm{C} 1^{\prime}$ & $\mathrm{C} 8, \mathrm{C} 2^{\prime}, \mathrm{C}^{\prime}$ \\
\hline $10 / 11$ & $3.77, \mathrm{~s}, 3 \mathrm{H} ; 3.88, \mathrm{~s}, 3 \mathrm{H}$ & $55.0 ; 55.1$ & $\mathrm{CH}_{3}$ & - & $\mathrm{C} 2 ; \mathrm{C} 5$ \\
\hline 12 & $2.60, \mathrm{q}, J=7.5,2 \mathrm{H}$ & 23.0 & $\mathrm{CH}_{2}$ & $\mathrm{C} 4, \mathrm{C} 13$ & $\mathrm{C} 3, \mathrm{C} 5$ \\
\hline 13 & $1.15, \mathrm{t}, J=7.5,3 \mathrm{H}$ & 13,5 & $\mathrm{CH}_{3}$ & $\mathrm{C} 12$ & $\mathrm{C} 4$ \\
\hline $1^{\prime}$ & - & 117.4 & $\mathrm{C}$ & - & - \\
\hline $2^{\prime}$ & 7.31-7.26, m, 1H & 131.2 & $\mathrm{CH}$ & - & $\mathrm{C} 9, \mathrm{C} 4^{\prime}, \mathrm{C}^{\prime}$ \\
\hline $3^{\prime}$ & $6.92-6.87, \mathrm{~m}, 1 \mathrm{H}$ & 119.3 & $\mathrm{CH}$ & - & $\mathrm{C} 2^{\prime}, \mathrm{C} 5^{\prime}$ \\
\hline $4^{\prime}$ & $7.31-7.26, \mathrm{~m}, 1 \mathrm{H}$ & 131.0 & $\mathrm{CH}$ & - & $\mathrm{C}^{\prime}$ \\
\hline $5^{\prime}$ & $6.92-6.87, \mathrm{~m}, 1 \mathrm{H}$ & 115.0 & $\mathrm{CH}$ & - & $\mathrm{C} 3^{\prime}$ \\
\hline $6^{\prime}$ & - & 156.1 & $\mathrm{C}$ & - & - \\
\hline
\end{tabular}

$D E P T$ distortionless enhancement by polarization transfer, $H M B C$ heteronuclear multiple-bond correlation, $J$ coupling constant, $M$ multiplicity, $s$ singlet, $t$ triplet, $q$ quartet, $m$ multiplet 
Table $4{ }^{1} \mathrm{H}$ and ${ }^{13} \mathrm{C}$ NMR spectral data for compound $\mathbf{0 2}(25 \mathrm{C}-\mathrm{NBOH})$ obtained at $600 \mathrm{MHz}$ (methanol- $d_{4}$ )<smiles>COc1cc(CCNCc2ccccc2O)c(OC)cc1Cl</smiles>

\begin{tabular}{|c|c|c|c|c|c|}
\hline \multirow[t]{2}{*}{ Position } & \multirow{2}{*}{$\begin{array}{l}{ }^{1} \mathrm{H}[\delta(\mathrm{ppm}), \mathrm{M}, J(\mathrm{~Hz}), \\
\text { Integral ] }\end{array}$} & \multirow[t]{2}{*}{${ }^{13} \mathrm{C}[\delta(\mathrm{ppm})]$} & \multirow[t]{2}{*}{ DEPT 135} & \multicolumn{2}{|l|}{ HMBC } \\
\hline & & & & ${ }^{2} J$ & ${ }^{3} J$ \\
\hline 1 & - & 123.9 & $\mathrm{C}$ & - & - \\
\hline 2 & - & 151.6 & $\mathrm{C}$ & - & - \\
\hline 3 & 7.03-7.00, br, $1 \mathrm{H}$ & 113.0 & $\mathrm{CH}$ & $\mathrm{C} 2, \mathrm{C} 4$ & $\mathrm{C} 1, \mathrm{C} 5$ \\
\hline 4 & - & 121.5 & $\mathrm{C}$ & - & - \\
\hline 5 & - & 149.3 & $\mathrm{C}$ & - & - \\
\hline 6 & $6.99-6.96$, brs, $1 \mathrm{H}$ & 115.2 & $\mathrm{CH}$ & $\mathrm{C} 5$ & $\mathrm{C} 2, \mathrm{C} 4, \mathrm{C} 7$ \\
\hline 7 & $3.02, \mathrm{t}, J=7.7,2 \mathrm{H}$ & 26.8 & $\mathrm{CH}_{2}$ & $\mathrm{C} 1, \mathrm{C} 8$ & $\mathrm{C} 2, \mathrm{C} 6$ \\
\hline 8 & $3.21, \mathrm{t}, J=7.7,2 \mathrm{H}$ & 46.5 & $\mathrm{CH}_{2}$ & $\mathrm{C} 7$ & $\mathrm{C} 1, \mathrm{C} 9$ \\
\hline 9 & $4.23, \mathrm{~s}, 2 \mathrm{H}$ & 46.7 & $\mathrm{CH}_{2}$ & $\mathrm{C} 1^{\prime}$ & $\mathrm{C} 8, \mathrm{C} 2^{\prime}, \mathrm{C} 6^{\prime}$ \\
\hline 10 & $3.78, \mathrm{~s}, 3 \mathrm{H}$ & 55.2 & $\mathrm{CH}_{3}$ & - & $\mathrm{C} 2$ \\
\hline 11 & $3.83, \mathrm{~s}, 3 \mathrm{H}$ & 56.0 & $\mathrm{CH}_{3}$ & - & $\mathrm{C} 5$ \\
\hline $1^{\prime}$ & - & 117.3 & $\mathrm{C}$ & - & - \\
\hline $2^{\prime}$ & $7.34-7.25, \mathrm{~m}, 1 \mathrm{H}$ & 131.2 & $\mathrm{CH}$ & $\mathrm{C} 9, \mathrm{C} 4^{\prime}$ & $\mathrm{C} 6^{\prime}$ \\
\hline $3^{\prime}$ & $6.93-6.87, \mathrm{~m}, 1 \mathrm{H}$ & 119.6 & $\mathrm{CH}$ & $\mathrm{C} 2^{\prime}, \mathrm{C} 4^{\prime}$ & $\mathrm{C} 1^{\prime}, \mathrm{C} 5^{\prime}$ \\
\hline $4^{\prime}$ & $7.34-7.25, \mathrm{~m}, 1 \mathrm{H}$ & 131.0 & $\mathrm{CH}$ & - & $\mathrm{C} 2^{\prime}, \mathrm{C} 6^{\prime}$ \\
\hline $5^{\prime}$ & $6.93-6.87, \mathrm{~m}, 1 \mathrm{H}$ & 114.9 & $\mathrm{CH}$ & $\mathrm{C} 6^{\prime}$ & $\mathrm{C} 3^{\prime}$ \\
\hline $6^{\prime}$ & - & 156.1 & $\mathrm{C}$ & - & - \\
\hline
\end{tabular}

For abbreviations except $b r$ broad and $b r s$ broad singlet, see Table 3 
Table $5{ }^{1} \mathrm{H}$ and ${ }^{13} \mathrm{C}$ NMR spectral data for compound $\mathbf{0 3}$ (25B-NBOH) obtained at $600 \mathrm{MHz}$ (methanol- $d_{4}$ )<smiles>COc1cc(CCNCc2ccccc2O)c(OC)cc1Br</smiles>

\begin{tabular}{|c|c|c|c|c|}
\hline \multirow[t]{2}{*}{ Position } & \multirow[t]{2}{*}{${ }^{1} \mathrm{H}[\delta(\mathrm{ppm}), \mathrm{M}, J(\mathrm{~Hz})$, Integral $]$} & \multirow[t]{2}{*}{${ }^{13} \mathrm{C}[\delta(\mathrm{ppm})]$} & \multicolumn{2}{|l|}{ HMBC } \\
\hline & & & ${ }^{2} J$ & ${ }^{3} J$ \\
\hline 1 & - & 124.8 & - & - \\
\hline 2 & - & 151.9 & - & - \\
\hline 3 & $7.16, \mathrm{~s}, 1 \mathrm{H}$ & 115.8 & $\mathrm{C} 4$ & $\mathrm{C} 1, \mathrm{C} 5$ \\
\hline 4 & - & 110.0 & - & - \\
\hline 5 & - & 150.0 & - & - \\
\hline 6 & $6.96, \mathrm{~s}, 1 \mathrm{H}$ & 114.7 & - & $\mathrm{C} 2, \mathrm{C} 4, \mathrm{C} 7$ \\
\hline 7 & $3.01, \mathrm{t}, J=7.6,2 \mathrm{H}$ & 27.0 & $\mathrm{C} 1, \mathrm{C} 8$ & $\mathrm{C} 2, \mathrm{C} 6$ \\
\hline 8 & $3.22, \mathrm{t}, J=7.6,2 \mathrm{H}$ & 46.5 & $\mathrm{C} 7$ & $\mathrm{C} 1, \mathrm{C} 9$ \\
\hline 9 & $4.23, \mathrm{~s}, 2 \mathrm{H}$ & 47.0 & $\mathrm{C} 1^{\prime}$ & $\mathrm{C} 8, \mathrm{C} 2^{\prime}, \mathrm{C} 6^{\prime}$ \\
\hline 10 & $3.79, \mathrm{~s}, 3 \mathrm{H}$ & 55.3 & - & $\mathrm{C} 2$ \\
\hline 11 & $3.83, \mathrm{~s}, 3 \mathrm{H}$ & 55.9 & - & C5 \\
\hline $1^{\prime}$ & - & 117.3 & - & - \\
\hline $2^{\prime}$ & $7.33-7.25, \mathrm{~m}, 1 \mathrm{H}$ & 131.4 & - & $\mathrm{C} 9, \mathrm{C} 4^{\prime}, \mathrm{C} 6^{\prime}$ \\
\hline $3^{\prime}$ & $6.93-6.87, \mathrm{~m}, 1 \mathrm{H}$ & 120.0 & - & $\mathrm{C} 5^{\prime}$ \\
\hline $4^{\prime}$ & $7.33-7.25, \mathrm{~m}, 1 \mathrm{H}$ & 131.0 & - & $\mathrm{C} 2^{\prime}, \mathrm{C} 6^{\prime}$ \\
\hline $5^{\prime}$ & $6.93-6.87, \mathrm{~m}, 1 \mathrm{H}$ & 114.6 & - & $\mathrm{C} 3^{\prime}$ \\
\hline $6^{\prime}$ & - & 156.1 & - & - \\
\hline
\end{tabular}

For abbreviations, see Table 3

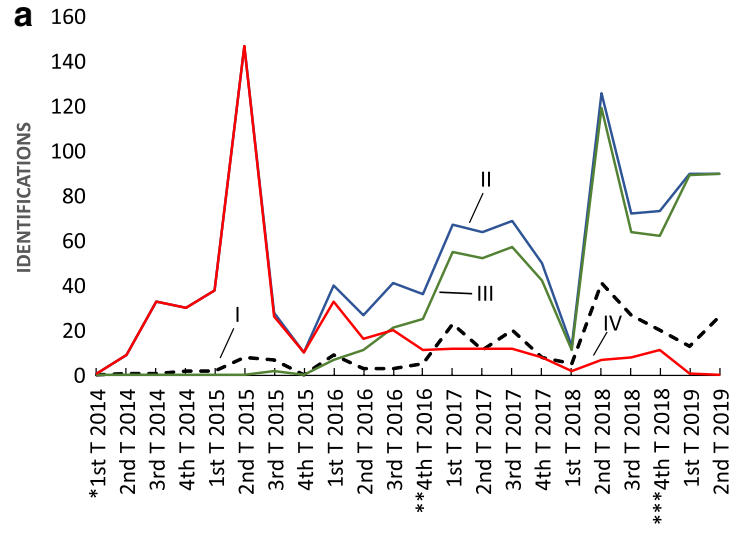

- - -I: LSD —II: N-benzylphenethylamines — III: NBOHs —IV: NBOMes

Fig. 9 Changes of $N$-benzylphenethylamine identification between first trimester (T) of 2014 and second trimester of 2019 (a) and NBOH identification between third trimester of 2015 and second

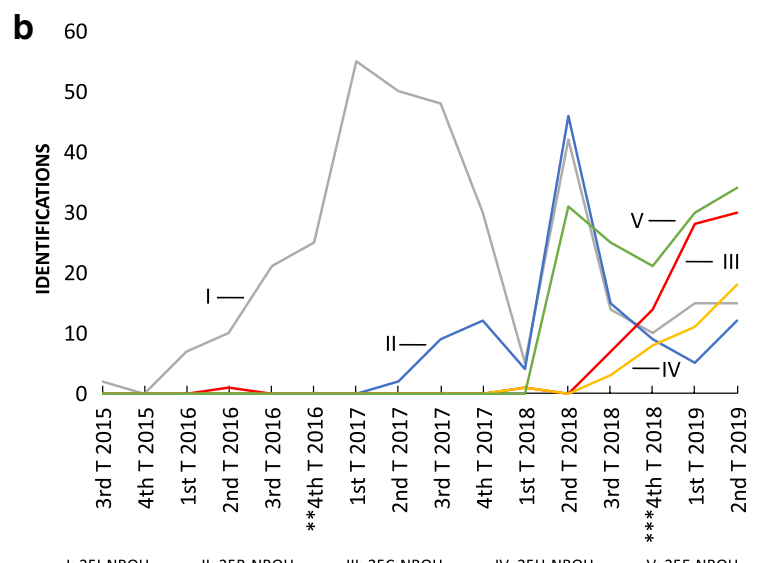

I: $251-\mathrm{NBOH}-I I: 25 \mathrm{~B}-\mathrm{NBOH}-\mathrm{III}: 25 \mathrm{C}-\mathrm{NBOH} \longrightarrow \mathrm{IV}: 25 \mathrm{H}-\mathrm{NBOH} \longrightarrow \mathrm{V}: 25 \mathrm{E}-\mathrm{NBOH}$

trimester of 2019 (b). Asterisk: local ban of several NBOMe substances; double asterisk: local ban of 25I-NBOH; triple asterisk: local ban of other $\mathrm{NBOH}$ substances 


\section{Conclusions}

The permanent emergence of NPS is, undoubtedly, a result of the efforts of drug dealers in circumventing drug controls. In this context, here we have presented data on the identification and structural characterization of three NPS, members of the NBOH class: 25B-NBOH, $25 \mathrm{C}-\mathrm{NBOH}$ and 25E-NBOH. To our knowledge, this is the first report to identify and to characterize these three substances in authentic street seized samples which have emerged in the Brazilian market after 25I-NBOH was scheduled. As predicted in a previously published work, we have confirmed that these three substances are thermolabile, degrading into the corresponding $2 \mathrm{C}-\mathrm{X}$ molecule during its injection in standard gas chromatography, easily leading them to be misidentified as such, a grave error from the forensic point of view.

Acknowledgements We would like to thank all our laboratory colleagues and Ms. Ivana Silva Lula (Departamento de Quí-mica, Universidade Federal de Minas Gerais) by carry out NMR experiments. José Coelho Neto is supported by FIP-PUC-MG ( Fundo de Incentivo à Pesquisa da Pontifícia Universidade Católica de Minas Gerais). Rosemeire Brondi Alves and Evandro Piccin are supported by $\mathrm{CNPq}$ (Conselho Nacional de Desenvolvimento Científico e Tecnológico) research fellowships.

\section{Compliance with ethical standards}

Conflict of interest The authors declare that they have no conflict of interest.

Ethical approval This article does not contain any studies with human participants or animals performed by any of the authors.

Open Access This article is distributed under the terms of the Creative Commons Attribution 4.0 International License (http://creativeco mmons.org/licenses/by/4.0/), which permits unrestricted use, distribution, and reproduction in any medium, provided you give appropriate credit to the original author(s) and the source, provide a link to the Creative Commons license, and indicate if changes were made.

\section{References}

1. United Nations Office on Drugs and Crime (UNODC) (2017) World drug report 2017-market analysis of synthetic drugs: amphetamine-type stimulants, new psychoactive substances. https ://www.unodc.org/documents/scientific/Booklet_4_Market_Analy sis_of_Synthetic_Drugs_ATS_NPS.pdf. Accessed 10 Jul 2019

2. United Nations Office on Drugs and Crime (UNODC) (2018a) Global SMART update- understanding the synthetic drug market: the NPS factor. https://www.unodc.org/documents/scientific /Global_Drugs_Assessment_2017.pdf. Accessed 17 Aug 2018

3. United Nations Office on Drugs and Crime (UNODC) (2018b) World drug report 2018 - analysis of drug markets: opiates, cocaine, cannabis, synthetic drugs. https://www.unodc.org/ wdr2018/prelaunch/WDR18_Booklet_3_DRUG_MARKETS.pdf. Accessed 15 Apr 2019
4. Nichols DE (2012) Structure-activity relationships of serotonin 5-HT ${ }_{2 \mathrm{~A}}$ agonists. WIREs Membr Transp Signal 1:559-579. https ://doi.org/10.1002/wmts.42 (open access article)

5. Hansen M, Phonekeo K, Paine JS, Leth-Petersen S, Begtrup M, Bräuner-Osborne H, Kristensen JL (2014) Synthesis and structure-activity relationships of $N$-benzyl phenethylamines as 5-HT $2 \mathrm{~A} / 2 \mathrm{C}$ agonists. ACS Chem Neurosci 5:243-249. https://doi. org/10.1021/cn $400216 \mathrm{u}$

6. Eshleman AJ, Wolfrum KM, Reed JF, Kim SO, Johnson RA, Janowsky A (2018) Neurochemical pharmacology of psychoactive substituted N-benzylphenethylamines: high potency agonists at 5-HT $2 \mathrm{~A}$ receptors. Biochem Pharmacol 158:27-34. https ://doi.org/10.1016/j.bcp.2018.09.024

7. Palamar JJ, Barratt MJ, Ferris JA, Winstock AR (2016) Correlates of new psychoactive substance use among a self-selected sample of nightclub attendees in the United States. Am J Addict 25:400-407. https://doi.org/10.1111/ajad.12403

8. Sutherland R, Bruno R, Peacock A, Dietze P, Breen C, Burns L, Barratt MJ (2017) New psychoactive substances: purchasing and supply patterns in Australia. Hum Psychopharmacol Clin Exp 32:e2577. https://doi.org/10.1002/hup.2577 (open access article)

9. Hannemann T-V, Kraus L, Piontek D (2017) Consumption patterns of nightlife attendees in Munich: a latent-class analysis. Subst Use Misuse 52:1511-1521. https://doi.org/10.1080/10826 084.2017.1290115 (open access article)

10. Machado Y, Coelho Neto J, Lordeiro RA, Silva MF, Piccin E (2019) Profile of new psychoactive substances (NPS) and other synthetic drugs in seized materials analysed in a Brazilian forensic laboratory. Forensic Toxicol 37:265-271. https://doi. org/10.1007/s11419-018-0456-3

11. European Monitoring Centre for Drugs and Drug Addiction (EMCDDA) (2017) EMCDDA-Europol 2016 Annual Report on the implementation of Council Decision 2005/387/JHA. https://doi.org/10.2810/430586

12. Drugs-Forum (2009) 25I-NBOH Experiences. https://drugs-forum .com/threads/25i-nboh-experiences.95632. Accessed 2 May 2019

13. Reddit (2014) NBOMe vs. NBOH. https://www.reddit.com/r/ Drugs/comments/1wj3v0/nbome_vs_nboh. Accessed 15 Apr 2019

14. Psychedelic Dad (2014) NBOH and NBOMe series. http://psych edelicdad.blogspot.com/2014/05/nboh-and-nbome-series.html. Accessed 15 Apr 2019

15. Arantes LC, Júnior EF, de Souza LF, Cardoso AC, Alcântara TLF, Lião LM, Machado Y, Lordeiro RA, Coelho Neto J, Andrade AFB (2017) 25I-NBOH: a new potent serotonin 5-HT ${ }_{2 \mathrm{~A}}$ receptor agonist identified in blotter paper seizures in Brazil. Forensic Toxicol 35:408-414. https://doi.org/10.1007/s11419-017-0357-x (open access article)

16. Coelho Neto J, Andrade AFB, Lordeiro RA, Machado Y, Elie M, Ferrari Júnior E, Arantes LC (2017) Preventing misidentification of 25I-NBOH as $2 \mathrm{C}-\mathrm{I}$ on routine GC-MS analyses. Forensic Toxicol 35:415-420. https://doi.org/10.1007/s11419-017-0362-0

17. de Morais DR, Barbosa IL, Cunha KF, Tripodi GL, Angolini CFF, Franco MF, de Aquino EM, Eberlin MN, Costa JL (2017) EASI-IMS an expedite and secure technique to screen for $25 \mathrm{I}-\mathrm{NBOH}$ in blotter papers. J Mass Spectrom 52:701-706. https://doi.org/10.1002/jms.3977

18. Souza GA, Arantes LC, Guedes TJ, de Oliveira AC, Marinho PA, Muñoz RAA, dos Santos WTP (2017) Voltammetric signatures of 2,5-dimethoxy-N-(2-methoxybenzyl) phenethylamines on boron-doped diamond electrodes: detection in blotting paper samples. Electrochem Commun 82:121-124. https://doi. org/10.1016/j.elecom.2017.08.001

19. Magalhães LdO, Arantes LC, Braga JWB (2019) Identification of NBOMe and $\mathrm{NBOH}$ in blotter papers using a handheld NIR spectrometer and chemometric methods. Microchem J 144:151158. https://doi.org/10.1016/j.microc.2018.08.051 
20. Ng XQ, Hamzah A, Ling M, Goh E, Moy HY, Yao YJ, Lui CP (2019) Qualitative analysis of synthetic opioids, synthetic hallucinogens and LSD in urine using LC-MS/MS. Aust J Forensic Sci 51:S229-S233. https://doi.org/10.1080/00450 618.2019.1568565

21. de Andrade AFB, Gonzalez-Rodriguez J (2019) Electroanalytical identification of 25I-NBOH and $2 \mathrm{C}$-I via differential pulse voltammetry: a rapid and sensitive screening method to avoid misidentification. Analyst 144:2965-2972. https://doi. org/10.1039/c9an00062c

22. Scientific Working Group for the Analysis of Seized Drugs (SWGDRUG) (2019) SWGDRUG IR library version 2.0. http://www. swgdrug.org/ir.htm. Accessed 10 Mar 2019

23. Republic of Slovenia, Ministry of the Interior Police (2017) Response ATR-IR library. https://www.policija.si/eng/index.php/generalpol icedirectorate/1669-nfl-page-response. Accessed 5 Aug 2018
24. Zuba D, Sekuła K (2013) Identification and characterization of 2,5-dimethoxy-3,4-dimethyl- $\beta$-phenethylamine (2C-G) - a new designer drug. Drug Test Anal 5:549-559. https://doi.org/10.1002/dta.1396

25. Chia XWS, Ong MC, Yeo YYC, Ho YJ, Nasir EIBA, Tan L-LJ, Chua PY, Yap TWA, Lim JLW (2019) Simultaneous analysis of 2Cs, 25-NBOHs, 25-NBOMes and LSD in seized exhibits using liquid chromatography - tandem mass spectrometry: a targeted approach. Forensic Sci Int 301:394-401. https://doi.org/10.1016/j. forsciint.2019.05.036

26. Agência Nacional de Vigilância Sanitária (ANVISA) (2019) Lista de substâncias sujeitas a controle especial no Brasil. http://porta 1.anvisa.gov.br/lista-de-substancias-sujeitas-a-controle-especial. Accessed 2 Apr 2019

Publisher's Note Springer Nature remains neutral with regard to jurisdictional claims in published maps and institutional affiliations. 